\title{
Psicopatologia/Metapsicologia. A função dos pontos de vista*
}

\section{Pierre Fédida e Patrick Lacoste}

Para o autor, é evidente que existe uma psicopatologia freudiana e que sua referência é incontornável. No entanto, ;é fato que as caracteristicas de sua "bandeira" permanecem imprecisas à medida que se negligencie o "metapsicológico" que compreende seu discurso. É preciso acrescentar também que o uso feito pelos psicanalistas do termo "metapsicologia" não está protegido das fortes influências ideologicas, em virtude das aspirações da psicanálise à "cientificidade".

Aproximando metapsicologia e psicopatologia, o autor trabalha o que ele considera como a invenção de uma perspectiva até então desconhecida, de uma perspectiva que define seu objeto indicando a posição do sujeito que observa: perspectiva do aparelho psíquico ha muito anunciada e posteriormente definida em termos de pontos de vista. 
O mês de agosto de 1911 via nascer em Leipzig a primeira Revista de psicopatologia, contemporânea da psicanálise. Wilhelm Specht, de Munique - um aluno de Kraepelin -, era seu diretor de redação. Segundo Jung, o "entusiasmo empático [de Specht] pela psicanálise" não foi suficiente para que um psicanalista fosse convidado a colaborar ${ }^{1}$ : Jung propunha a Freud considerar o empreendimento desta Revista como concorrente. Aos olhos de Freud, o ponto crítico deste caso deveria ser julgado tendo como pressuposto que não se poderia pretender aliança com a psicanálise sem decidir-se falar sobre isto alto e bom som. $\mathrm{Na}$ verdade, a apresentação do primeiro volume era ambígua e o oferecimento de aliança estava subterrâneo - Specht tendo endereçado uma carta pessoal a Freud quando escreveu, em sua introdução publicada, que as "experiências verdadeiras da psiquiatria clínica" eram contraditas pelas teorias de Freud que havia "construído arbitrariamente as noções de base psicológicas de que se serve, sem relacioná-las com a psicologia" 2 . Ferenczi, leitor atentíssimo deste primeiro número, via nele, sobretudo, um exercício de "pilhagem intelectual" de idéias freudianas e julgava que tudo isto não era, em essência, senão a psicanálise navegando com uma falsa bandeira"3.

Quase um século depois, tornou-se evidente que a palavra psicopatologia não poderia se satisfazer com uma só "bandeira". Mas é também evidente que existe uma psicopatologia freudiana e que sua referência é incontornável. No entanto, é fato que as características de sua "bandeira" permanecem imprecisas - até mesmo aleatórias - à medida que se negligencie o "metapsicológico" que compreende seu discurso. Aliás, há já muito tempo que várias psicopatologias bastardas navegam sob a bandeira psicanalítica e que a própria bandeira freudiana não está mais garantida nem certificada pela denominação de "psicanálise". Entre psicanálise e psicopatologia hoje, as aventuras de terminologia não mascaram mais apenas a referência possível a bandeiras verdadeiras ou falsas, mas confundem ainda mais as cores

1. Freud-Jung. Correspondance, vol. II, carta de 6 de outubro de 1911, pp. 201-202. Paris, Gallimard, "Connaisance de l'inconscient", 1975.

2. Freud-Ferenczi. Correspondance, vol. I, carta de 5 de outubro de 1911, n² 1, p. 318. Paris, Calmann-Lévy, 1992. (Grifo nosso)

3. S. Ferenczi, ibid., p. 362. A primeira publicação dos "freudianos" era anunciada sob o título Jahrbuch für Psychoanalyse und Psychopathologie. 
anunciadas por "bandeiras de complacência". Acrescentemos, enfim, que o uso feito pelos psicanalistas do termo "metapsicologia" não está protegido das fortes influências ideologicas - principalmente em virtude das aspiraçōes profissionais à famosa "cientificidade" da psicanálise - e que um abuso intelectual do prefixo meta conduz, por precipitação tendenciosa, a querer designar o mesmo estatuto epistemológico à noção de modelo em biologia ou neurobiologia, em neuropsicologia, em psicanálise etc. As relaçōes interteóricas não são impossíveis desde que previamente assegurada a especificidade de cada abordagem.

Quem, de início, fosse contrariado pelo privilégio dado ao anedótico e à insistência da metáfora poderia também ser alertado novamente sobre a necessidade psicanalítica de levar a sério tanto a metáfora como o anedótico. Questão de terminologia, de nomeação e definição, em suma: o trabalho de nominação está $\mathrm{cm}$ primeiro plano no projeto de reflexão sobre os modelos téricos, particularmente no que se refere às teorias do psíquico. Tratando-se da exploração das relaçōes entre psicopatologia e metapsicologia - próprias para introduzir uma reavaliação que nos parece, doravante, impor-se -, a ênfase de um simples detalhe deveria bastar: o fato de que Freud tenha tornado público o projeto e os princípios de uma "metapsicologia" precisamente sob o título de Psicopatologia da vida cotidiana (1901-1904), pouco após tê-la fundado sem nomeá-la, teorizando o "aparelho psíquico" em A interpretação dos sonhos (1900), e bem antes de produzir a primeira grande tentativa para sua definição (1915).

Poder-se-ia lamentar que os psicanalistas sejam ainda intimados a justificar o interesse que têm pelos detalhes: lembraremos com Freud que 6 difícil "superar o hábito psicanalítico" de tirar conclusōes importantes a partir de pequenos sinais ${ }^{4}$. Com Freud, 6 , na verdade, a medida dos sinais que muda na história da psicopatologia, assim como é a partir da redução da importância dada aos sintomas que a metapsicologia se desenvolve. Até a psicanálise, a psicopatologia estava fundada sobre um descritivo dos sintomas de doença mental, dissociandose dificilmente da semiologia médica e da nosografia psiquiátrica. Conhece-se o debate inaugural de Freud com a semiologia e a nosografia de sua época - debate esquematicamente "controlado" pela questão da etiologia das neuroses, por um lado, e pelo problema das localizaçōes cerebrais, por outro - em um primeiro movimento, Freud desloca a concepção da psicopatologia, acrescentando-lhe a consideração não mais apenas dos sintomas de doenças repertoriadas, mas sinais de expressão do psiquico inseridos no funcionamento "normal" habitual e do qual a "doença" apenas reproduziria caricaturas ou aumentos. Advindo daf uma

4. S. Freud, carta a Ferenczi de 23 de janeiro de 1912, in Correspondance, I, p. 352, op. eit. (Grifo nosso) 
transformação da noção de etiologia, com a etiologia sexual das neuroses constituindo o eixo principal desta transformação. Este movimento tinha sido precedido por uma operação de deslocamento, que se inscrevia em contracorrente com as tendências localizacionistas (desde 1891, com Contribuição à concepção das afasias), para estabelecer uma fronteira suficiente entre o cérebro e o aparelho psíquico - fronteira traçada principalmente a partir do "esquema psicológico da representação de palavra". Conseqüentemente, uma variante apareceu, recrutando mais e com maior precisão discursos e representaçóes no campo do psicopatológico. Assim as palavras e os nomes se encontrariam ao mesmo tempo direcionados para a condição de sintoma e introduzidos em sua função de sinal psiquico pelo estabelecimento de uma fronteira paradoxalmente "deslocalizadora", uma ficção teórica - uma ficção necessária ao discernimento e útil à teoria.

Convém notar que a origem do discernimento freudiano de forma alguma é dissociável de um trajeto de individualização no desenrolar de polêmicas em que certos nomes servem como balizas: Charcot para a etiologia, Meynert para as localizaçōes, por exemplo. Tal notação seria ridícula se os dados biográficos fossem absolutamente independentes - em total objetividade - das intençōes teóricas, ou seja, se não se tratasse de falar de psicanálise em voz alta. O que implicaria o abandono, em beneficio suspeito da objetivação, das especificidades do método prático e térico da psicanálise. Não tem mais fundamento negligenciar a idéia de que um jovem pesquisador, Freud, queria "dar seu nome a um território cerebral" (ou mesmo ligar seu nome, assim como seus predecessores, a um sintoma, à descoberta de uma substância, de uma técnica etc.) nem esquecer o explícito chamamento à transferência, formulado como uma advertência ao leitor, em $A$ interpretação dos sonhos.

\section{Qualquer ciência - escreverá Freud, em 1938 - repousa sobre} observaçōes que nosso aparelho psíquico nos transmite, mas como 6 justamente este aparelho que estudamos, a analogia pára por aqui.

Entre a invocação inicial à transferência do leitor e a afirmação, no final do percurso, de um ponto de parada para a analogia, desenha-se toda a questäo da metapsicologia - enquanto núcleo conceitual e, por assim dizer, mestre de obras - para a psicopatologia freudiana.

A psicanálise se alinha, inicialmente, com o ponto de vista de uma psicopatologia empírica clássica que faz do sintoma "o ponto de partida da observação". Mas dividindo o sintoma e reduzindo o peso do patológico para a psicologia, Freud alerta o clínico para o "fato de estar consciente" do sintoma, para seu estatuto de consciência, e convida, em vista de uma psicologia do inconsciente, a conceber que se possa emancipar do sintoma, sem para isso esquecê-lo ou negligenciá-lo. É por isso que a metapsicologia considerará 
simultaneamente uma abordagem descritiva direta (em consciência) e uma abordagem que leva em conta sistemas tópicos (supondo a priori um conhecimento). O que não significa que os sistemas tópicos sejam concebidos extcrnamente à solicitação da clínica! Pode-se perceber que a evolução destes na obra de Freud depende largamente das transformações do campo da clínica psicanalítica (ver a função que desempenha, sob este ponto de vista, a neurose obsessiva $)^{5}$. Além disso, a prática analítica dá toda a chance para que se perceba que um sintoma dispõe de uma constituição e de uma função psíquica que assumem singularmente o papel de analogon do aparelho psíquico ${ }^{6.7}$. No entanto, mesmo sob o ponto de vista em que o inconsciente, enquanto sistema, está supostamente em causa, por um lado, a noção de "determinismo psíquico" modifica as relaçōes de causalidade que a etiologia havia prescrito e, por outro, a referência aos conceitos maiores da metapsicologia (pulsăo, recalcamento, inconsciente, objeto perdido, mecanismo do sonho, filogênesc...) não $\varepsilon$ independente da manutenção de uma tensão especulativa como princípio clínico, inclusive na teorizaçăo. A medida desta tensão está indicada por um outro tipo de advertência freudiana:

É preciso lembrar-se de que nossas hipóteses podem apenas almejar o valor de representaçōes figuradas (do aparelho psiquico). ${ }^{8}$

Não se poderia, de forma alguma, economizar a reflexão - por mais sucinta que seja - que trata de duas palavras Bild (imagem) e Vorbild (modelo ou protótipo). Se partirmos novamente da corporeidade do sintoma histérico, perceberemos que a inagem é nele potência de imitação e, como se vê em Charcot, a observação toma emprestado um tipo de fenomenologia mimética para descrever o sintoma reproduzindo-o (cf. os trabalhos de Georges DidiHuberman). Em Freud, a corporeidade da Bild (do sintoma) leva a um esquema corporal do psíquico. É neste sentido que o aparelho psíquico do capítulo VII de A interpretação dos sonhos originou-se, justamente, da memória estratificada do corpo histérico, mas por intermédio do trabalho do sonho. O esquema é de execução e alcance metapsicológicos, mas dispōe da corporeidade da Bild. Na análise de pacientes obsessivos, poder-se-ia mostrar que se trata de integrar a corporeidade do sintoma (histeria e/ou sonho) no esquema da Bild, onde o "dialeto" tende a produzir a ilusão de um puro discurso do psíquico. De certa forma, na psicanálise, o Vorbild (metapsicológico) afirma a Bild: o "modelo" constitui assim

5. P. Lacoste. Contraintes de pensee, contrainte a pensé. Paris, PUF, 1992.

6. P. Fedida. Crise et contre-transfert. Paris PUF, 1992.

7. P. Lacoste, op. cit.

8. S. Freud. "L'inconscient" (1915), in Metapsychologie. Paris, Gallimard, 1976. 
uma estranha normalidade metapsicológica - estranha na verdade, porque esta normalidade dispōe de uma heurística ficcional. Em contrapartida, dir-se-ia que o próprio da Bild está em sua capacidade de deformação. É por isso que o "psicopatologico" não poderia ser observado externamente a uma consideração filogenética.

Não e certo que se tenha suficientemente avaliado a incidência da metapsicologia sobre a psicopatologia - incidência representativa comparável aos efeitos da invenção da perspectiva em pintura ou em arquitetura. Pois trata-se justamente da invenção de uma perspectiva, até então desconhecida, de uma perspectiva que define seu objeto indicando a posição do sujeito que observa: perspectiva do aparelho psíquico há muito anunciada, depois definida em termos de pontos de vista. Talvez não seja somente à "feiticcira" do primeiro Fausto que a metapsicologia deva sua apelação freudiana heroicizada (1937) - modo de especulação particular, até mesmo atividade fantasmática específica da teorização em psicanálise -, mas também à memória coletiva, sempre fascinada, destes espelhos convexos - aos quais podem-se atribuir algumas funçōes mágicas, a ponto de chamá-los "feiticeiras" - que dão a perceber um espaço condensado, deformado, cujo reflexo, repentinamente convidativo, os inquieta, com a maior curiosidade, indicando há séculos a representaçăo de um método de projeção (mesmo que legível nas costas de uma colher polida) muito anterior aos avanços da geometria, que tornaram possível a compreensão científica. No entanto, as analogias espaciais também têm um limite, a espacialidade do aparelho psíquico não se condensa com a mesma facilidade, projetivamente, sobre o aparelho de linguagem como o espaço real se lança, com o auxílio de algumas leis de representação, sobre um plano arquitetônico. Ora, as palavras que pretendem dizer sempre mais do que a figura obrigam, as vezes, os usuários mais aplicados a deixar transparecer suas fraquezas, ceder, inclusive, à tentação de "fazer um desenho". Além disso, as palavras mais comuns da teoria, ao se tornarem "senhas", têm, elas próprias, as mesmas tendências a se compactarem, a mascararem alguma falta de simetria durante o uso, justamente o tipo de falta que ainda permitiria tomar conhecimento da condensação operada pela linguagem.

Se o esquema freudiano - com vocação metapsicológica de Vorbild ("modelo" ou protótipo) - provém da Bild (a imagem enquanto "histeria" ou "sonho") e sua escritura é diagramática (no sentido peirceano), sua inspiração pelos aparelhos 6́pticos (telescópio ou microscópio) coloca a questão de uma estrutura perspectiva (sentido do "ponto de vista"), graças a qual o modelo de percepção é modificado. Em outras palavras, o esquema-Vorbild instaura uma física da proję̧ão (uma "optica") assim como uma tópica da regressāo baseada no inconsciente e não na percepção-consciência (a consciência 6 um órgăo 
sensorial). A ficção do aparelho óptico e da imagem formada pela estrutura e a disposição das lentes vêm tornar possível a escritura esquemática da imagem. Atendo-se a uma definição estrita, dir-se-ia que não se pode ter metapsicologia que não seja do inconsciente (no sentido que lhe é dado pelo texto de 1915) e que daí a "observação", "construção", "projeção", "nominação" (língua e linguagem) não poderiam, de forma alguma, referir-se à consciência. Adivinhase facilmente a incidência destas considerações sobre o psicopatológico, que no limite não pode ser proveniente nem de uma psicologia da consciência, nem deve pressupor - sob o modo de um neo-jacksonismo - que o inconsciente é a arquitetônica do consciente. Para Freud, a consciência não poderia ser uma instância. No rastro destas proposiçōes, coloca-se mais claramente a questão de uma impossível metapsicologia do inconsciente em Lacan (que conserva implicitamente a referência instancial à consciência). E este seria, sem dúvida, o desenvolvimento reflexivo destas proposiçōes que autorizaria discernir, entre os psicanalistas, aqueles que se alinham decididamente à posição freudiana do problema e aqueles que se afastam, conservando, no entanto, o uso do mesmo "vocabulário"

O eixo de simetria do termo "psicopatológico" é, além disso, mal assegurado, já que este último se presta tanto aos discursos cujo objetivo é a psicologia ou a patologia, quanto aos discursos cujo ponto de partida é uma psicologia ou uma patologia - sem falar das dificuldades as quais as grandes classificaçōes nosográficas condenam a mínima elaboração de uma psicopatologia desde o instante em que não se trata mais de "abandonar" o sintoma assim repertoriado... Pode-se, no entanto, observar que Freud opera uma escolha em sua língua, utilizando, simplesmente, "psicopatologia" (termo de tradição filosófica e médica) em vez de "psicologia (do) patológico" (em uso pelos psicólogos) ou ainda de "patopsicologia" (expressão bastante freqüente em alemão). A construção do termo "metapsicologia" produz, aliás, um efeito diferente de simetria, se imaginarmos que o prefixo meta năo vem unicamente modificar o sentido e o alcance de "psicologia", mas que talvez venha substituir a primeira parte de Patopsicologia e, certamente, infletir em espelho a relação de psico para patologia.

A denominação/nominação engaja o fundo, e, para se livrar dele, poder-seia invocar o argumento segundo o qual é uma simples questão de terminologia! Imaginemos que, do início do século até aproximadamente 1940, a questão de fundar a psicopatologia e, correlativamente, de assentar a psiquiatria clínica em bases "científicas" (e antropológicas) está no centro de vários debates. A título de exemplo: foi em 1913 que apareceu a primeira edição do livro de Karl Jaspers, Allgemeine Psychopathologie que, segundo o autor, tende a substituir "o sistema de base teórica" por "uma ordem de base reflexivo-metodológico" 
(Ordnung auf Grund methodologisher Besinnung). Trata-se, portanto, de refletir - a partir da psiquiatria - uma psicopatologia que se oferece, de maneira autoconstitutiva, a psicologia que lhe é indispensável; e, conseqüentemente, tratase de promover um novo método de abordagem dos fatos psicológicos em geral. Comparativamente, o caminho traçado por Ludwig Binswanger nos interessa muito mais aqui - em particular porque ele acolhe o pensamento de Freud e a ele se opóe fortemente. Em 1922, é publicado Einfuhrung in die Probleme des allgemeinen Psychologie - verdadeira introdução ao esclarecimento das noçōes fundamentais às quais o psiquiatra clínico pode recorrer em sua sensibilidade, pensamento $\mathrm{e}$ ação junto ao doente. Algumas contribuições de Ludwig Binswanger nesta época: "Psychoanalyse und klinische Psychiatrie" (1920), "Über Phänomenologie" (1922), "Welche Aufgaben ergeben sich für Psychiatrie aus den neuen Fortschritten der Psychologie" (1924), "Erfahren, Verstehen, Deuten in der Psychoanalyse" (1926). A distinção de Binswanger entre uma psicopatologia empírica e uma psicopatologia fenomenologica (fundada pela fenomenologia transcendental de Husserl) faz com que siga um caminho absolutamente filosófico que torna, por isso, muito aleatória uma verdadeira harmonia com Freud cuja relação psicopatologia/metapsicologia repousa justamente na "transposição da metafísica em metapsicologia". A respeito do projeto de Binswanger, pode-se ler o trabalho de Serge Valdinoci, "Binswanger: uma metafísica da psiquiatria"." Também é verdade que há historicamente determinaçōes semânticas - de origem psicanalítica e fenomenológica - relativas a "psicopatologia". Do ponto de vista aqui adotado, tal junção 6 discutível. Merece ser, todavia, reconhecida tanto no prolongamento da escola húngara de psicanalise com Szondi (Schotte e a escola de Louvain falam de psicopatologia no sentido de uma pato-análise), quanto para marcar a função assumida pelo psicopatológico na acepção de uma intersubjetividade da contratransferência ${ }^{10}$. É neste mesmo sentido que H. Maldiney compreende fenomenologicamente o pathei-mathos do Agamenon de Ésquilo (o vivido do sofrimento constituído em experiência) ou que Harold Searles, em sua prática psicanalítica junto a esquizofrênicos, confere ao psicopatológico uma função transubjetiva (contratransferencial).

Mas a acepção freudiana do psicopatológico năo poderia privilegiar uma fenomenalidade às custas do sintoma. A irredutibilidade do sintoma na psicanálise requer a necessidade do sinal e do processo psíquico a partir das "formas" que o patológico assume.

9. In P. Fedida. Phenominologie, psychiarie, psychanalyse. Paris, Centurion, 1986.

10. P. Fedida. Crise et contretransfert, op cit. 
Levado a reivindicar ao longo do tempo os fatores etiológicos propostos pela psicanálise, Freud não hesitaria $\mathrm{cm}$ afirmar:

A saúde, justamente, não se deixa descrever de outra forma que não metapsicologicamente, com referência a relaçōes de força entre as instâncias do aparelho da alma que reconhecemos ou, se preferir, supomos, deduzimos."

"Saúde": termo pouco esperado na escrita de Freud, que - em relação a uma tarefa da metapsicologia - conviria muito mais por sua identificação conceitual que o de "normalidade", por ser muito marcado em sua definição e por estar em oposição ao patologico.

\section{Reconhecer. Nomear}

A idéia de descrever as relações de força entre as instâncias do aparelho psíquico - tendo como princípio a metapsicologia - aparece nas cartas a W. Fliess durante 0 ano de 1894, principalmente no plano que concerne à etiologia e à teoria das grandes neuroses (Manuscrito D): ela 6 orientada pelas primeiras tcorias da excitação interna e pela teoria da constância. Um salto exemplar para se afastar do domínio da etiologia e da nosografia - primeira tentativa para se emancipar do sintoma "psiquiátrico" - dará origem ao "Projeto para uma psicologia científica" de 1895 . Na verdade, não enfatizamos suficientemente o modelo que representa o esboço de "psicologia científica" para a metapsicologia, pelo menos nestas duas direções: a pretensão precoce de descrever um funcionamento normal (trata-se aqui de normalidade) - modelo para o objetivo - e a intenção constantemente retardada, mas repetitivamente operada com as maiores precauções, de produzir uma síntese-modelo para o resultado. Sobre este último ponto, a não publicação do "Projeto", a destruição de uma grande parte dos ensaios metapsicológicos (1915), o caráter inacabado do Esboço de psicanálise (1938) sāo constataçōes (quaisquer que sejam as razōes) que apenas alertam sobre as relações do fundador com a exposiçăo de uma teoria geral, que, no entanto, é nomeada de doutrina (die Lehre). Sem dúvida, é preciso ver aqui não apenas a recusa de chegar a sinteses ("os sintomas se encarregam disto! Inclusive da cura), mas através desta recusa a de evitar, para a metapsicologia, a sorte, por assim dizer, esquizofrênica da filosofia. Como o indica, principalmente, o texto sobre "O inconsciente" de 1915:

Quando pensamos abstratamente, corremos o risco de negligenciar as relaçōes das palavras com as representaçōes de coisa inconscientes e năo se

11. S. Freud, "Lanalyse avee fin et l'analyse sans fin" (1937), p. 241, $\mathrm{n}^{2} 2$, in Résultats, idées, problèmes. Paris, PUF, 1985, (Grifo nosso). 
pode negar que nossa filosofia reveste, em sua expressão e conteúdo, uma semelhança que näo desejamos nela encontrar com a forma com que os esquizofrenicos operam.

O mesmo texto havia começado com uma referência à concepção fillośfica do inconsciente definido a partir da consciência. Notemos, portanto, que na passagem está perfeitamente claro que o "psicopatológico", podendo ser caracterizado a partir da "expressão" e do "conteúdo" de um discurso - aqui com vocação de síntese -, demarca o raciocínio em negativo se este é psicanalítico e tende, pois, a proposiçōes de natureza metapsicológica. Pois, afinal, a questão se reduz àquela da natureza do texto metapsicológico - entre logos e mythos e constituindo-se, de maneira híbrida, pelos dois ao mesmo tempo.

Pois assim como "a doutrina das pulsōes" será apresentada como a mitologia dos psicanalistas, supor-se-á que o trabalho do sonho detém o schibboleth - as "senhas" cuja compreensāo designa os adeptos e sem as quais a psicanalise permaneceria definitivamente incompreensivel a quem quisesse fazer sua economial2 - , parece que a função mitopoiética e a funçāo de reconhecimento da elaboração metapsicológica foram reservadas para um longo caminho intrateórico, e assim preservadas por uma série de hesitações, intuitivas ou deliberadas. Toda a visão de conjunto deveria constantemente ceder o passo tanto no pensamento quanto no texto - diante do particularismo e diversidade dos pontos de vista. Sem o que, ela se tornaria uma visão de síntese. Ao privilegiar o fragmentário $\epsilon$, não somente, a indicação dada da irrealização - função do asymptotisch -, mas isto em virtude de um raciocínio por inferências negativas, em virtude do negativo inerente a atividade de pensamento psicanalítico. Podese inclusive dizer que o analítico do sintoma passa por af e se quisermos alegar que tanto a síntese como a cura devem acontecer, a posição do analista é a de não fazer dela sua própria representação. Em certo sentido, a síntese, como a felicidade dos filósofos, deve acontecer, mas psicanaliticamente, por definição, nāo deve ainda se realizar. Por exemplo, o milagre da cura pelo amor de transferência - milagre do sintoma e sintoma-milagre - justifica que o analista nunca perca de vista a função psicopatológica da transferência e a função simpática da normalidade.

Em 1925, em sua "auto-apresentação", Freud retorna a esta questão da seguinte maneira:

Em frases anteriores de minha obra, ja fiz a tentativa de chegar a pontos de vista mais gerais* a partir da observaçäo analítica. Em 1911, enfatizei em

12. S. Freud. "Revision de la théorie du rêve". In Nouvelles conferences. Paris, Gallimard, "Connaissance de l'inconscient", 1984, p. 13. 
um pequeno ensaio, "Formulação sobre os dois princípios do funcionamento psíquico" [...], a predominância do princípio de prazer-desprazer para a vida psíquica e a maneira com que é substituído pelo que chamamos "princípio de realidade". Mais tarde, lancei-me na tentativa de uma "metapsicologia". Nomeei, assim, um modo de analise* no qual cada processo psíquico é apreciado em função das trés coordenadas da dinámica, da tópica e da economia, e nela vi o objetivo ultimo ao qual poderia atingir a psicologia*. Esta tentativa permaneceu em esboço, interrompi após alguns tratados [...] e fiz certamente bem, pois o tempo de tal fixaça teórica ainda não tinha chegado, ${ }^{13}$

Na verdade, Freud restabelece seu direito à especulação a partir da frase seguinte ("Em meus últimos trabalhos especulativos...") e esta passagem nāo pode ser compreendida hoje sem a observaçäo do parágrafo anterior acrescentado em 1935 (e omitido na Gesammelte Werke, publicada em 1948), que permite compreender que o problema essencial não estava ligado a fixação teórica, mas aos perigos da generalizaçāo conceitual pelo modo com que ela pode ser recebida.

Sempre experimentei como uma injustiça grosseira o fato de que não se quisesse tratar a psicanalise como qualquer outra ciência da natureza [...] Censuramos à psicanálise cada uma de suas incompletudes e imperfeiçōes, enquanto uma ciência fundada sobre a observação pode, no entanto, apenas destacar seus resultados pedaço a pedaço e resolver seus problemas passo a passo.

A acusação de pansexualismo dirigida à teoria psicanalítica - "reconhecendo" exatamente em seu lugar a função sexual - procede do contra-senso tendencioso sobre o próprio princípio de generalidade. $O$ mesmo para a ênfase do acidental no desenvolvimento, que teria permitido supor que a psicanálise anularia, assim, o constitucional e a hereditariedade... A desqualificação da psicanálise procede de um "desconhecimento radical do problema". Algumas linhas acima, Freud escreve:

Conceitos fundamentais claros e definiçōes com contornos nítidos não são possíveis nas ciências do espírito senão a medida que estas queiram englobar um domínio factual no quadro de um sistema intelectual constituído. Nas ciencias da natureza, entre as quais a psicologia, tal clareza dos conceitos superiores é supérflua, e mesmo impossível [...]; a biologia nāo sabe, ainda hoje, dar conteúdo certo ao conceito de ser vivo. ${ }^{14}$

13. Sigmund Freud presente par lui-méme. Paris, Gallimard, "Connaissance de I"inconscient", 1984. pp. 98-99. (Grifos nossos assinalados pelos asteriscos.)

14. S. Freud, ibid, p. 98. (Grifos nossos) 
A indeterminação das "representaçōes fundamentais" e dos conceitos é a condição do movimento próprio de teorização: "a progressão da análise do material observado" é o método que, justamente, evita a precipitação sobre as síntese generalizadoras.

É fato que, no corpus freudiano, a metapsicologia deve ser, doravante, reconstruída pedaço por pedaço, e que sua própria constituição, a partir da não finalização do "Projeto" de 1895 , foi feita passo a passo até 1938 , quando se encontra este modo de análise absolutamente intato $\mathrm{em}$ Moisés e o monoteísmo - principalmente nos propósitos dedicados aos "progressos na vida espiritual". É que a obra de Freud luta permanentemente contra a assimilação da doutrina ao dogma e que ela, apesar do esforço, nunca parou de a ela se contrapor. A psicanálise paga, sem dúvida, assim a obstinação de seu fundador em querer encurralar e denunciar a religiosidade de pensamento, o que comodamente se tomou por uma vaga especulação sobre as religiōes e, talvez, os sucessores de Freud nāo tenham tirado disto as liçōes de cuidado que teriam sido úteis aos funcionamentos e aos efeitos desta religiosidade tanto em suas teorias quanto em suas comunidades. Alem disso, se Freud tinha algumas razóes de, no início do século, queixar-se de que "a desconfiança dos psiquiatras [havia] posto a alma sob tutela", alguns sucessores certamente muito acrescentaram no que se refere à alma - o uso corrente alemão deixando-se muito naturalmente levar a tratar "da alma" como "do psíquico" - a ponto de, deliberadamente ou não, onde a religiosidade cedeu, aparentemente, as delícias do estetismo, ao espontaneísmo suspenso, à auto-referência como o psitacismo, invadirem pouco a pouco o campo da especulação, a ponto de, às vezes, atenuar consideravelmente - não sem, algumas vezes, as melhores intençōes pedagógicas - o vivo do exercício de teorização em psicanálise. O intelecto e as políticas relacionais teriam, assim, conseguido, por um lado, de dentro, o que as recusas externas e as objeções não teriam alcançado sozinhas: demolir o bastião mais estrategicamente colocado, para construir atrás diversas fortalezas magníficas - frequientemente concorrentes - em torno de elementos que não parecem necessariamente como valendo ser protegidos (exceção feita aos argumentos mais narcísicos).

Falar das interações do intelecto e das políticas relacionais com referência à metapsicologia justifica-se na presença de vários dados biográficos oferecidos pela correspondência de Freud e que näo param de solicitar uma leitura analítica. Na verdade, se a metapsicologia e "a mitologia" dos psicanalistas, se seus termos são "as senhas dos adeptos", deveríamos evitar, senão uma psicopatologia do movimento psicanalítico, pelo menos uma consideração do fato de que a teoria psicanalítica nasceu da patologia e que - como nenhuma outra teoria - enriqueceuse e se propagou a partir dos descolamentos progressivos e sucessivos, dos próprios "teóricos", de suas respectivas patologias, analisando-se uns aos outros 
- o que permanece como princípio da formação dos psicanalistas... Esta única consideração - a clínica psicanalítica está no centro da transmissão da psicanálise - convida, no mínimo, a não se negligenciar completamente os elementos de análise, a interpretação das relaçōes entre teoria e transferência, elementos de que o leitor menos atento dispōe, de agora em diante, abundantemente e dos quais os analistas não poderiam impunemente abrir mão.

Teríamos razão em atribuir a grande capacidade de autocrítica de Freud o fato de que não tenha publicado, nem "concluído" este ou aquele texto. Seria, talvez, imprudente não observar que se trata de escritos em que a atividade de síntese predomina e em que a especulação está presente de maneira muito evidente. O fato de estes materiais "recalcados" virem a tona é uma homologia ao método. O fato de estes "recalcamentos" participarem - quase sempre - das adversidades de uma relação transferencial năo expōe aos assaltos de psicobiógrafos mais ou menos dissimulados, mas reforça o interesse de falar sobre a psicanálise em voz alta.

Pode-se, por exemplo, observar que pouco após ter abandonado o projeto de escrever uma "psicologia científica", Freud chama novamente (de modo tímido) a atenção de Fliess sobre "algumas questões metapsicológicas" (Carta de 2 de fevereiro de 1896). Um ano mais tarde, na carta em que se livra de sua neurotica (de uma teoria de sua neurose), conclui assim:

...Concedo sempre mais prêmios a meu começo na metapsicologia. (Carta de 21 de setembro de 1897)

No ano seguinte, quando Freud se encontra em plena redação de $A$ interpretação dos sonhos, agradece seu "visual amigo de Berlim" por ter sonhado que seu livro estava terminado - como se o sonho de Fliess tivesse realizado o desejo de Freud - e lhe fala justamente de sua descoberta de que a interpretação pela realização do desejo não dá uma "solução biologica [mas] sim uma solução metapsicológica" (Carta de 10 de março de 1898). Segue-se, entre parênteses, a conhecida frase:

Aliás, é preciso que você me diga seriamente se posso dar à minha psicologia que acontece nos bastidores do consciente, o nome de metapsicologia. ${ }^{15}$

Este nome näo será tornado público em $A$ interpretação dos sonhos, apesar de figurar no plano detalhado no primeiro terço (Carta de 22 de julho de 1899), mas dois anos após, quando a relação com Fliess estiver perto de seu fim e Freud

15. S. Freud. La naissance de la psychanalyse, ef. pp. 143 e 193, para as citaçōes sucessivas, Paris, PUF, 1956. (Grifos nossos) 
puder dispensar sua "autorização". Seria este pedido de autorização um teste terminológico, uma hesitação submetendo-se à crítica benevolente, um empréstimo a Fliess que teria incidentemente forjado a palavra, o nome? Conhecem-se as idéias de Fliess, suas teorias, ele era um grande construtor de sistemas teóricos, não recuando ante síntese alguma - mesmo que absurda - e Freud não hesitará, em várias oportunidades, ante o "diagnóstico" de paranóia a seu respeito.

Reconhecer e nomear seu próprio funcionamento psíquico, os mecanismos do aparelho psíquico, o funcionamento psíquico do crítico eleito de sua teorização, levará Freud a publicar o nome "metapsicologia" afastando-o justamente do mecanismo da paranóia, numa simetria inversa.

\section{Projetar. Transpor}

Em vez de dar seu nome a um território cerebral, Freud vai promover um simples qualificativo: psíquico e elevá-lo, pelo substantivo, ao nível conceitual. No final de sua obra, no Esboço, a questão retornará:

\section{... a que série de fenomenos deve-se reservar o qualificativo psiquico?}

Esta questão está escandida por um trabalho incessante sobre o domínio verbal e a nominação, trabalho orientado pela busca de representaçōes-palavra para as coisas inconscientes e (esquematicamente) por duas metáforas para o recalcamento - o recalcamento é, primeiramente, apresentado como uma "falha de tradução", depois, a medida que o recalcado parece definir as fronteiras de uma "terra estranha" (Ausland), a metafora tradutiva se torna mais abstrata (o recalcado $\varepsilon$ na verdade estranho a qualquer lingua), a hipótese da dupla inscrição se destaca, enquanto mecanismo, das analogias de escrita, e a noção de Entstellung (deformação, desfiguração), primitivamente utilizada para descrever o sintoma, se instala no centro dos mecanismos do aparelho psíquico, para designar o problema do apagamento dos traços. Do tema inaugural do esquecimento dos nomes ao tema final do apagamento dos traços, a perspectiva do psíquico progressivamente se instalou, instaurando a representação de uma grande distância entre dois pólos aparentemente muito próximos.

É, pois, sob o título de Psicopatologia da vida coridiana, que o nome "metapsicologia" aparece. Em relaçāo à abordagem do sintoma, $\epsilon$ justamente a dimensão da vida cotidiana que funda a distinção entre a metapsicologia freudiana e a psicopatologia tal como era anteriormente concebida. Devemos lembrar que este livro, Psicopatologia da vida cotidiana (1901-1904), serviu durante muito tempo de "bandeira" para a psicanálise junto ao público mais amplo, sendo muito rapidamente traduzido e amplamente divulgado, e que Freud o modificou, completou e anotou durante mais de vinte anos. (O Homem dos ratos resolveuse por uma consulta após ter "folheado" esta obra.) 
O décimo-segundo e último capítulo deste livro: "Determinismo - Crença no acaso e superstição - pontos de vista", retoma o conjunto das hipóteses para inscrevê-las novamente nos "limites do estado normal", e 6 a parte pontos de vista que anuncia a posição metapsicológica a partir da qual um "modo de análise" será fundado. Na passagem, o método da Einfall (a associação livre das idéias) será introduzido pelo exemplo (em torno nos nomes e dos números), e a "força de associação" servirá à diff́cil definição de um determinismo psíquico "sem solução de continuidade" (que deixa intata a conviç̧ão do livre arbítrio) inacessível a uma lógica consciente habitual. O paranóico, em seu apego aos detalhes mais insignificantes permite ilustrar o problema da pesquisa de motivação, que passa pela projeção na vida psíquica de outrem daquilo que existe no estado inconsciente na sua. É a maneira de ver do paranoico que, por ser a caricatura de um funcionamento não censurado, permite chamar a atenção sobre os graus de interpretação: há verdade na interpretação delirante do mundo externo ("verdade" que escaparia ao homem normal) e o fato de convencer o leitor desta parte de verdade paranóica deveria tornar mais suportáveis estas verdades da interpretação freudiana que facilmente seriam consideradas loucuras. Em suma, Freud parece tomar como base um fundo paranóico mínimo e comum para contornar... a desconfiança do leitor: um pouco de paranóia bastaria para admitir o determinismo inconsciente, assim como o paranóico autêntico o indica de modo geral para a consciência - é uma logica delirante que (a exemplo do aparente absurdo do sonho) servirá de modelo para introduzir as logicas do inconsciente...

A partir de então, como convencer sobre a não-existência do acaso interno (psíquico), sem refutar o acaso externo (real)? A superstição e a crença serão substituidas, temporariamente, uma pelo funcionamento da hipótese e a outra pela construção da teoria. Superstição e crença, assim como o sonho é um delírio normal, seriam as formas elementares da construção delirante, os exemplos de uma dupla logica acessivel, por um lado, a qualquer um, e por outro, inacessivel sem interpretação: o supersticioso assim como o crente utilizam externamente a motivação que a psicanálise procura no interior; o que é projetado sobre o acontecimento será "abrandado" no pensamento. Interpretar o caso em termos de ignorância consciente e conhecimento inconsciente leva a propor que a concepção mitológica, e depois religiosa, do mundo "nada mais é que uma psicologia projetada no mundo externo". É aqui que a analogia com a paranóia ć uma "construção de apoio", ela funciona como modelo para uma outra lógica. A percepção endopsíquica do inconsciente - que não é um "verdadeiro" conhecimento - se projeta reflexivamente sobre o mundo e constrói uma realidade que ultrapassa o testemunho dos sentidos (superstição - crença - delírio), e esta realidade supra-sensivel deve ser retransformada, pela ciência, em psicologia do inconsciente. O programa de teorização é esboçado desta forma: 
Poder-se-ia se dar como tarefa decompor, colocando-se desde este ponto de vista, os mitos relativos ao paraíso e ao pecado original, a Deus, ao mal e ao bem, a imortalidade etc. e transpor a metafisica em metapsicologia. ${ }^{16}$

Programa para um ponto de vista, cuja leitura atenta da obra de Freud pode constatar a realização com relação ao essencial, e que deveria alertar sobre a inutilidade de dissociar posteriormente a psicopatologia freudiana de todas as reflexōes - por "invasão audaciosa" - sobre a cultura e a civilização para esclarecer o psíquico e, também, para esclarecê-las pelas leis do psíquico.

O raciocínio fundador da metapsicologia repousa, pois, sobre um modelo psicopatológico: a paranóia, um modelo psicológico: a projeção, e implica uma retransformação do primeiro, uma transposição do segundo. $\mathrm{Na}$ verdade, os dois modelos são reunidos, dez anos mais tarde $\mathrm{em}$ Totem e tabu, pela proposição de que o animismo 6 um protótipo (Vorbild) de sistema intelectual. Mas já neste capítulo da Psicopatologia, a conjunção dos modelos está preestabelecida, por um lado, com o assinalamento da "forma de pensar" metapsicológica: conferir importância e tirar conclusōes do menor sinal (segundo a linha de deslocamento operado pelo "olhar agudo do paranóico"); e, por outro, com a abertura do campo de estudo do pensamento primário - a resolução antropomórfica do mundo situando sobre planos paralelos de igual importância o ponto de origem para o deslocamento térico: os primórdios do pensamento no individuo, os primordios do pensamento no humano. A superstição era apenas o complemento lógico do conhecimento pré-científico, e a direção meta da logica psicanalítica deve evitar funcionar por complementos sucessivos desde o momento em que o risco de projetar as formas secundarizadas da lógica sobre o pensamento primário resultaria na anulação do tempo da constituição psíquica. $O$ antropomorfismo teria, de algum modo, um correlato: o "psicomorfismo" que induziria a atribuição de uma forma lógica constituida (na consciência) à observaçāo dedutiva de uma pluralidade de logicas (inconscientes) em vias de constituição e participando da constituição. Paranoia, superstição e crença são modelos atuais (para a psicopatologia e para a psicanálise), c a projeção metapsicológica tende a estabelecer seu funcionamento inatual (em relação a protótipos), dando sua versão paradoxalmente retemporalizada em relação ao passado (ontogênese e filogênese). Resulta daí o postulado freudiano que pode ser resumido pela proposição de que o raciocínio por inferéncia (o eixo da projeção meta) faz apelo a uma nominaçāo e a uma logica que absorvem o tempo ao longo de uma descrição para construir suas referências de espacializaçāo psíquica, o ponto de vista tópico.

16. S. Freud. Psychopahologie de la vie quotidienne (pp. 277-321 para o conjunto das citaçoes e formulaçōes resumidas). Paris, Payot, 1960. (Grifos nossos) 
O determinismo psíquico pode construir o passado para interpretar o inatual, enquanto, conscientemente, a superstição coloca o futuro em condição, a crença o submete - assim como o presente - ao eterno, ao passo que a paranóia sujeita, sempre conscientemente, o futuro, como o presente, a projeção que condiciona sua própria existência. Superstição, crença e paranóia orientam diferentemente a consciência para a anulação do passado, constituindo talvez uma forma de ação dos graus do esquecimento psíquico (e do psíquico); são as formas clínicas extremas (do mais cotidiano ao mais patológico) da exclusão mútua da memória e da consciência, exclusão, inicialmente, postulada pela primeira tópica. É concebivel que estas questōes de tempo subjacentes à exposição do projeto metapsicologico tenham levado Freud a redigir uma longa nota, em 1924, acrescentada ao fim deste capítulo, para modificar e argumentar sua concepção do esquecimento; nota na qual se encontra a afirmação de que o "inconsciente se encontra, de modo geral, fora do tempo", a análise dos traços de lembranças recalcadas levam a constatar que a duração, a idade e o tempo interno em nada mudam.

Todo mecanismo de projeção interpreta uma realidade desconhecida qualquer, exclusivamente a partir do já-conhecido, e produz uma antecipação: quanto mais a projeção for "motivada", mais seus motivos serāo, ao mesmo tempo, recalcados. A consciência 6 , pois, transformada em projetor, em órgão dos sentidos que só pode perceber a partir de uma cegueira sobre o interior. Dir-se-ia que, para a projeção, todo o interno é passado, não é mais atual. É justamente isto que a metapsicologia considera, literalmente, voltando a projeção para o mundo interno, para fornecer um estado dos lugares... do tempo. O ponto de vista do projetor, do observador, já é, neste sentido, uma transposição do que é um ponto de vista: é o dispositivo de esclarecimento da mancha cega. Resultando daí a aposta que representa o deslocamento metapsicológico enquanto psicopatologia da transferência.

É bastante notável que a "personagem" do paranóico se encontre convocada nesta situação-pivô $\mathrm{em}$ que - em favor de uma teoria da projeção - trata-se de transpor a metafísica em metapsicologia. Isto é ainda mais notável quando, ao fazer a economia da transferência para privilegiar a intersubjetividade, a psicopatologia filośfica da mesma época apela para a fenomenologia transcendental de Husserl para colocar o problema do outro estranho a partir da qual se constitui um método de investigação para a psiquiatria clínica. Mas se a questão do "outro" se torna, como se sabe, uma formulação cômoda no discurso psicanalítico de nossa época - é preciso convir que foi bem pouco explorada a "condição" psicopatológica da paranóia no tratamento psicanalítico. Pois não se trata somente de falar de "paranoização" da transferência e da contratransferência em certos casos (modo de operar uma redução psicopatológica de natureza psiquiátrica sobre um processo); tratar-se-ia, antes, de determinar que lugar vem 
ocupar a pessoa do analista em relação ao paciente de forma que a projeção se apodere das pessoas em vez de continuar a regular a dinâmica dos processos transferenciais. Esta é uma outra maneira ainda - dir-se-ia - de recolocar o problema psicopatologia/metapsicologia, avaliando a significaçāo que assume a palavra "pessoa" no pensamento de Freud (cf. o sonho, o traço de espírito...).

\section{Física e psicologia}

Neste contexto, o que significa a expressão: transformar a metafísica em merapsicologia?

Sem sombra de dúvida, o emprego que Freud faz do termo "metafísica" nāo $\mathcal{E}$, propriamente falando, técnico: nāo repousa sobre uma pesquisa histórica da evolução filosófica de seu uso desde Aristóteles. Levando em conta o interesse de Freud pela obra de Kant, pode-se legitimamente pensar que ele entra em acordo com este para recusar como vā a metafísica tradicional enquanto "ciência das coisas em si" ("Näo há e [...] năo poderia haver metafísica", diz Kant). Esta ciência das coisas em si escandaliza a razäo e a experiência: tudo o que lança como afirmação sobre a alma, o mundo e Deus é, na falta de uma crítica prévia, puramente peremptório, pois é enunciado como objetos inacessíveis. Somente a Crítica pode servir de fundamento a uma metafísica legítima possivel. Nenhuma dúvida, portanto, de que Freud torne globalmente sua esta posição racional. Dela resultaria que a metafísica ć simplesmente o nome genérico para a imaginação filosófica de uma realidade supra-sensivel. Mas - como deixamos entender, sob um determinado aspecto, Freud não se preocupa necessariamente com uma distinção entre metafísica e filosofia ou, mais exatamente, denunciaria - assim como Kant - de que maneira a filosofia da loucura $e$ inútil quando a metafísica $e$ vã. Neste sentido, os filosofos do inconsciente são metafísicos que teriam abandonado previamente sua imaginação poética popular.

Não podemos tratar aqui da relaçấo de Kant com a problemática da loucura, magistralmente desenvolvida por Monique David-Ménard em seu recente livro $A$ loucura na razão pura - Kant leitor de Swedenborg. ${ }^{17}$ E deixamos deliberadamente de lado a questão da psicopatologia kantiana - psicopatologia clínica desde que seja crítica -, passando pelas possibilidades de condiçōes diferenciais da percepção e da existência de outrem. A influência de Kant sobre a nosografia psiquiátrica não é negligenciável: o pensamento kantiano conduz, na verdade, a uma categorialização no que tange as doenças do espírito. Ler-se-á o Ensaio sobre as

17. M. David-Ménard, La folie dans la raison pure. Kant lecteur de Swedenborg. Paris, Vrin, 1990. 
doenças da cabeça (1764), em que Kant mostra todo o interesse que tem pelas alucinaçóes e hipocondria. E sabe-se que Kant tomou a paranóia como modelo exemplar da psicopatologia da razão e da comunicação com outrem ${ }^{18}$.

"Transpor a metafísica em metapsicologia" vem a ser, para Freud, construir uma realidade interna emancipada da percepção endopsíquica, ultrapassando talvez superando - qualquer observação que reúna os testemunhos dos sentidos. Mais uma vez, a expressão poderia ser de caráter kantiano se em Kant se tratasse de passar para uma psicologia; mas a operação freudiana não $\epsilon$ de natureza filosófica, nem está em nome da razão. A operação consiste, como veremos, èm desarticular a própria palavra metafísica, já que o nome e seu prefixo devem, de certa maneira, reaparecer na metapsicologia.

Repentinamente, a aposta freudiana consiste em uma objetivação racional (científica) do mais racional, daquilo de que o subjetivo não pode esperar ter a medida. Objetivação semelhante estaria ao alcance do subjetivo desde que o alçasse não a uma função intersubjetiva, mas hipersubjetiva. E como não poderia estar aqui em questão a subjetividade, a não ser que reintegrasse a instanciação da consciência, é preciso que a racionalidade da operação assuma onde estão de onde emanam - as entidades-crenças da metafísica, a saber, no próprio cerne do animismo da humanidade. A transposição não deve efetuar uma pura e simples substituição nem uma Aufhebung intelectual. Ela deve recolher e conservar a fonte das crenças metafísicas, transpondo-as para esta "mitologia" que $\varepsilon$ a metapsicologia.

O jogo de formulação do radical meta leva, pois, ao mesmo plano dos nomes aparentemente também tāo distantes como "física" e "psicologia". Ora, a metapsicologia não é uma psicologia "meta" - ou seja, mais geral - e também não é uma racionalidade discursiva sobre a psicologia (como o seria, por exemplo, a "metalingǘstica"). A operação de transposição graças ao meta - que também trans e além -, caso conduza à designação da psicologia do inconsciente, é, na verdade, ao mesmo tempo, uma física do aparelho psíquico e literalmente uma metafisica... do psíquico. Não apenas porque o modelo da tensão especulativa interna requerida $c$ o da conjetura (posição teorizante à qual as ciências físicas conferiram estatuto científico), mas também porque a conceituação metapsicológica, mesmo que "mitológica", toma-se, de certa forma, como materialismo do psiquico, e ainda porque a metapsicologia é uma teoria de aplicação, tanto da teoria quanto da clínica psicanalíticas. Este pensamento sobre o físico, sobre o psíquico não se abre para um fisicalismo, ou seja, para uma

18. Ver P. Fedida, "La paranora comme theorie de la communication". In Le temps de la reflexion. 5. Paris, Gallimard, 1984. 
modelização mecanicista (é o contra-senso de Binswanger e de outros na interpretação da noção de aparelho psíquico): ele engaja mais radicalmente a acepção primeira de uma physis em sua significatividade "psíquica".

Certamente, a esperança de constituir o real por teorias é o princípio de qualquer especulação, mas a interpretação do real advindo da abordagem científica mudou de estatuto com os progressos do experimental. Também não é uma questão menor, no início do século, querer construir uma teoria da realidade psíquica visando o real, sem se distanciar muito da prática da experiência clínica. Em Freud, querer manter juntas experiência e especulação - ligar uma à outra e uma pela outra em um mesmo movimento - se mantém. É este movimento teoria/ clínica que parece ter engajado Freud nos terrenos metapsicológicos cada vez mais metafísicos. A partir de 1920 - em "Além do princípio de prazer", o artigo talvez mais exemplar da indissociável mistura entre raciocínio clínico e especulação - até 1938 (em suas notas), vê-se, na verdade, a metapsicologia se tornar, em movimentos súbitos, cada vez mais audaciosa. O que chamaremos "a virada de 1920 ", radicalizando as proposições teóricas ao formulá-las em uma condicionalidade crítica protegida do dogmatismo, corresponde também à vontade de não deixar a "terapêutica matar a ciência" e manter ainda mais firmemente as aquisiçōes metapsicologicas, duramente ganhas, ancoradas na observação psicopatologica. Que se trate do masoquismo, da clivagem do eu, da culpa inconsciente, da reação terapêtica negativa, da fecundidade da oposição entre neurose e psicose etc., vê-se que o pensamento do patológico - a doença humana - $\epsilon$ uma fonte ainda mais potente de inspiração e especulação metapsicológicas, que faz com que o sopro aumente. A audácia "metafísica" da metapsicologia de Freud reforça, pois, em contrapartida, o aspecto "psicopatologico" abrupto do olhar que o analista deve guardar em sua clínica.

Outro paralelo entre metafísica e metapsicologia: uma e outra parecem admitir tantas definições quantos praticantes há, em função das épocas (a preocupação de definição não sendo, é verdade, comparável em nenhum caso nos dois campos). Em certo sentido, Freud herda, sem dúvida, uma concepção "bárbara" da metafísica: o conhecimento dos princípios gerais de uma arte ou de uma ciência, assim como os enciclopedistas a reduziram, opondo as ciência do espírito à física. Este dualismo dos ideólogos atenuava, com certeza, o da "Lógica de Port-Royal", que defendia uma distinção absoluta da alma e do corpo, uma separação entre as idéias espirituais e as imagens corporais, distinção que certamente Freud não teria querido para a psicanálise, mas cuja forma dualista atenuada permitia uma disposição "técnica" propícia para a pesquisa - em particular para uma física da alma. Vários psicanalistas teriam, de bom grado, seguido Sully Prudhomme, aqueles para quem a metapsicologia "começa onde a clareza acaba"... É, no entanto, bastante notável encontrar nos contemporâneos 
de Freud referências tão diferentes quanto as de Bergson - a metafísica seria a ciência que pretende prescindir dos símbolos, um conhecimento absoluto por intuição direta das coisa - e os de William James - "a metafísica é apenas um esforço particularmente obstinado para pensar de uma maneira clara e consistente", em seu Textbook of psychology... Isto para ilustrar a dificuldade terminologica imediata de uma proposição de aparência tão simples quanto "transpor a metafísica em metapsicologia", em uma época em que muitos já se ocupavam em transpor a metafísica... em filosofia.

A fórmula se tornou célebre pela facilidade, ao passo que indicava justamente o esforço obstinado que restava ser feito para pensar de maneira consistente, para pensar o inconcebível e conceituar o impensável. Talvez houvesse espaço para ressituar o debate inaugural da metapsicologia, mais do que com a mefísica em geral, por exemplo, com a metalógica de Schopenhauer, esta verdade que repousa imediatamente sobre a constituição do espírito (pelo menos para os princípios de identidade e contradição, que têm certo peso na teorização freudiana). Talvez também deva-se reinterpretar um certo desprezo pela metapsicologia em duas direçōes da história das idéias: o domínio da dialética e o domínio do cientismo.

Sabe-se que Hegel tomava a metafísica pelo seu pior lado, vendo nela um dogmatismo ontológico. O marxismo seguiu seus passos, vendo nela apenas um método que estuda as coisas enquanto objetos fixos dados, um materialismo estreito, incapaz de considerar o mundo enquanto processo e desenvolvimento histórico. (Para Lênin, admitir uma essência imutável das coisas era apenas um "materialismo metafísico", antidialético.) Não se poderia esquecer de que houve suficientes psicanalistas marxistas (antes ou durante sua relação com a psicanálise), para evitar considerar a possibilidade de uma influência da ideologia sobre uma eventual piora da metapsicologia, repousando sobre uma leitura crítica parcial, que se baseia nas "fixações teóricas", que renega, aliás, naturalmente (ainda hoje) a idéia de processo que comporte, inicialmente, o destino das pulsões e a idéia de desenvolvimento histórico que representa o ponto de vista filogenético. Em suma, para não ver a dialética na metapsicologia, era preciso aceitar alegremente enganar-se de metafísica...

Quanto ao domínio do cientismo, sua interpretação estaria curiosamente ligada ao domínio da dialética. Criticando o materialismo metafísico do século XVIII, remetendo-o sempre ao nível que atingiram as ciências naturais da época, os novos Ideólogos não consideraram de forma alguma o fato de que "metafísica" já era bastante pejorativo para os enciclopedistas, a ponto de o Dicionário inscrever, em 1798, o verbo metafisicar em um novo arsenal verbal contra os ressurgentes do sofisma. Este tom pejorativo se acentuou no curso das relaçōes entre filosofia e ciência; quanto mais os filósofos se tornavam "cientistas", mais a metafísica, em seu sentido primeiro aparecia em seus escritos como vã e obscura 
filosofia, propícia à logomaquia. Pode-se efetivamente ignorar a hipotese de um movimento comparável a este hoje: quanto mais os psicanalistas se tornaram "cientistas" - sob a pressão da ciência, mas principalmente do cientismo (a vulgarização das neurociências em particular) -, mais a metapsicologia, na acepção freudiana pareceu-lhes obscura e vã, propicia somente aos processos verbais, sendo, além disso, um pouco desconfortável, por seu frenesi de neogênese conceitual e de vocabulário importado?

Em um limite entre mundo interior e mundo exterior, aí onde o princípio de realidade opera e opõe-se ao princípio de prazer, as expressóes constituem, poder-se-ia dizer, a parte "física" da psicologia. As imagens corporais e as funçōes verbais, os afetos, as percepções, as apresentações e as representações se combinam em diversos níveis. A fala e a linguagem também sāo "corpos" em que se projetam a vida do espírito e a existência do psíquico, são os materiais da metapsicologia, materiais que fazem apelo a uma linguagem em construção, cuja lei de deslocamento não é apenas a metáfora no sentido da retórica, pois a teoria do sonho soube extrair a metáfora do estilo para restituí-la ao conhecimento. É justamente a metapsicologia que exigia a lembrança, por Lacan, de que não há metalinguagem, no momento em que a linguística retransformava a metafora em sintoma, pelo fato de que a metapsicologia convida ao desdobramento de uma língua em posição meta, tanto em relação à linguagem, quanto $\mathrm{em}$ relação ao corpo. O fato de os conceitos constituírem "uma língua" para o território de conhecimento que visam delimitar, requer que a epistemologia examine seu funcionamento, coerência e validade. Para não cair sob a acusação de metapsicologizar, é útil que os psicanalistas se interroguem sem cessar sobre as relaçōes de suas metapsicologias com a metapsicologia freudiana. Resultando daí a necessidade de se perguntar periodicamente, como o fazia recentemente Daniel Widlöcher ${ }^{19}$. se a metapsicologia se tonou - ou se torna - "uma língua morta".

Um obstáculo crítico, uma rocha da metapsicologia, reside, sem dúvida, na dificuldade de manter a idéia diretriz acoplada a uma consideração da prematuridade biológica do humano - da prematuridade do psíquico em relação à linguagem e, também, em relação ao pensamento. Qualquer teorização, uma vez constituída em teoria, expōe-se incessantemente ao risco de querer impor sua linguagem, chegando ao ponto em que esta linguagem daria representação do fato de os pensamentos que the correspondem preexistirem à atividade de pensar.

O schibboleth da metapsicologia não se permitiria explicar sem deixar imediatamente de ser um schibboleth! A comunidade suposta de um esperanto ou de uma linguagem computacional! - léxico da metapsicologia ilude no que se

19. D. Widlocher. Merapsychologie du sens. Paris, PUF, 1986. 
refere à identidade das questōes. "Inconsciente", "recalcamento", "pulsăo", "transferência", "Édipo", "castração" etc. parecem poder obedecer a definiçōes unívocas e mesmo convir à axiomática do enquadre, da técnica e da formação padrão psicanalítica. Mas como năo se render à evidência de que o schibboleth sempre escapa? Pode-se, então - com o auxílio da vulgarização -, pretender que a metapsicologia é "um sistema conceitual". Ou ainda, pode-se representar a tolerância histórica e sustentar que existem metapsicologias - kleiniana, lacaniana, bioniana -, a cada vez fazendo da metapsicologia o equivalente de uma teoria constituída, mas não se interrogando para saber se é possivel, neste ou naquele caso, falar de metapsicologia. Enfim, não é de forma alguma seguro que seja possível afirmar que qualquer conceito seja "metapsicologizável" - mesmo que esta formulação faça sentido.

\section{Paralínguas}

O fato é que - e isto não é uma simples história - os psicanalistas franceses viveram por muito tempo em um erro de tradução da fórmula freudiana que convida a "traduzir [em vez de 'transpor'] a metafísica em metapsicologia". Este detalhe, bastante anódino, abre, no entanto, a possibilidade de imaginar algumas consequiências históricas - principalmente a de uma forte ambivalência em relação à tradução acompanhada por uma atividade intensa da atitude tradutora.

Sob o impulso da posição primeira (leitor-tradutor) de Lacan, e pelo fato de ele arregimentar o "lingüístico", anexando-o, um certo número de debates franceses desembocaram no aparecimento do Vocabulário da psicanálise, que respondia, assim, a uma necessidade da tradução, mas constitura também uma "máquina de guerra" sobre o território já dividido dos freudianos. Hoje em dia a julgar pelas várias citações do Vocabulário - as definições em negrito são superestimadas em relação à tentativa inovadora de teorização que o corpo dos artigos constitui e tal corte serve para inverter no leitor novo o sentido do projeto dos autores: se a leitura concede uma primazia para a definição dos vocábulos em detrimento do conhecimento dos textos, é então anulado o essencial; $́$ é que Hegel teria chamado de "automovimento do conceito". Na época, saldado por Nicolas Abraham em seu conceito de anassemia, o Vocabulário da psicanálise visava, em certo sentido, um estabelecimento do texto freudiano em língua francesa e fazia, pois, de seus autores os tradutores-editores em potencial das Obras completas. Mas não é inútil lembrar que o empreendimento - de tradução e edição - estava inicialmente voltado contra Lacan, apesar de não ignorar qual era sua dívida para com ele. Do ponto de vista em que aqui nos colocamos, não poderíamos negligenciar, por um lado, a escolha que resultou, em Lacan, de um discurso que se pretendia exclusivamente reservado aos seus adeptos (e não aos 
adeptos da psicanálise) e, por outro, outras escolhas efetuadas pelos autores do Vocabulário visando, de maneira diferente, é verdade, prosseguir sua tarefa. Este simples lembrete - cujo desenvolvimento aqui não faz sentido - $\epsilon$, no entanto, o da história do movimento psicanalítico. A responsabilidade da fala no analista exige, na verdade, de sua parte, a consciência desta história em que está engajado. Um texto psicanalítico, quaisquer que sejam as abordagens teóricas - sendo, inclusive, isento de qualquer "ilustração" clínica - deixa entender as palavras da prática de seu autor. Estaríamos tentados a dizer que um texto 6 metapsicológico à condição que sua escrita abra para sua clínica - ou seja, que suas palavras sejam responsáveis pela fala do paciente. E há pouca chance de poder trabalhar com um conceito metapsicológico se este conceito, ao se pensar, não recebe a reflexividade de sua história. Tratando-se do Vocabulário da psicanálise, conviria, na verdade, saber se a metapsicologia encontra nele sua própria fonte ou se ele não engaja por sua concepção e projeto uma lógica contraditória à da metapsicologia. Mas esta $́$ uma discussão crítica que não podemos desenvolver aqui e que será abordada em um trabalho posterior.

A tentaçăo poética, mallarmeana, de Lacan de forma alguma 6 um segredo, ela atuou tanto em suas leituras tradutoras como na poiesis de seu discurso. Esta questão veio complexificar a apreensão possível da relação dos analistas, de seus grupos, com o idioleto, com a formulação idiomática - e, certamente, também porque aí mergulharam em sua prática -, e mesmo com o hermetismo e a jargonofasia. É próprio do destino das fórmulas inspiradas como ondas de uma pedra na poça; a difusão mais ampla está mais longe do ponto de impacto e a percepção persistente na superfície recalca a percepção da dissimulaçăo; o maquinário linguageiro que pode proteger um grupo, ao mesmo tempo "militante" e ameaçado, pode sempre voltar, avançando - aos que ele não converte ou não evangeliza, aparecerá naturalmente como maquinação.

Quando Lacan foi "excomungado", fundou uma escola, "sozinho"... E seus antigos alunos, por sua vez, fizeram o mesmo, em "conjunto"... De um lado e de outro, durante anos, houve uma mudança de língua, na mesma língua. De um lado, o evitamento das concepções lacanianas anteriores provocou uma neogênese do vocabulário, a pesquisa de outras referências; depois, veio o tempo das "obras", e sempre a marca de um desvio, de uma gigantesca paráfrase para evitar, contornar, o nome, as palavras, de Lacan, que, por sua vez, produziu um silêncio igualmente espesso, dando prosseguimento à invenção de um discurso. Não se pode excluir que a tentação mallarmeana foi então arrolada, pelo menos no início, contra os antigos alunos: os novos não falarão mais a mesma língua; os ingratos, aqueles que souberam tirar proveito de um ensino e "jogar fora" o mestre, năo estarão mais "por dentro", não mais se acharão aí. Assim, a psicanálise na França, em um tempo histórico muito curto, se "babelizou" em 
francês, e os modos de falar se fixaram um pouco, marcados em suas diferenças, tornando-se signos de pertença.

De um lado, evidentemente, encorajou-se muito cada um a encontrar suas próprias palavras, de outro, cada um se apropriava das palavras do mestre: a democracia absoluta reinava em todos os lugares. E depois, Lacan deu novamente o golpe da Babel, não por cisão, mas por dissolução. Ele morreu, sua língua aumentou e se multiplicou. Vinte anos após, ainda havia alguns poliglotas, mas não havia mais nenhum mosqueteiro, havia guardas vermelhos e guardas de museu; vinte anos após, a questão de uma "língua morta" - a metapsicologia freudiana desta vez - ressurgiu.

A literatura francesa 6 assim; houve Mallarmé, houve Valéry que, apesar de sua obra e seu trabalho furioso, talvez nunca tenha se curado de seu grande predecessor, seu mestre e amigo. Mas Lacan năo era exatamente Mallarmé, apesar de algumas vaidades sonoras c de scus bibelôs suprimidos, vendidos nos leilões, c de seus contemporâneos, seus sucessores, não freqüentarem mais as mesmas academias... Além disso, as questōes - por mais que a psicanálise ainda as mantenha - estão muito longe de serem literárias. Outra coincidência é justamente quando a edição dos Seminários de Lacan - suas obras completas - está em debate, diante inclusive dos tribunais, a questão das obras completas de Freud em francês volta à ordem do dia (e os processos por serem de um outro gênero, não são menos violentos). A menos que a coincidência não se leia no sentido inverso. Observemos também que as particularidades da língua traduzida e do discurso transcrito estão no centro do debate. Questỏes de sucessão, fidelidade e "patrimônio"...

E se, por acaso, os postulantes a tradutores que assimilam a interpretação e a tradução estivessem na origem de uma nova Babel? Uma mudança de língua na mesma língua, um novo lexico delimitando um novo território francês? O problema não está ao nível das intenções, boas ou más, mas ao nível das perspectivas de utilização, em função das repetiçōes na história recente. A questão não seria senão aquela de um léxico "justo" ou não, a partir do momento em que faz desaparecer tudo, especialmente as palavras que se tornaram as principais palavras em uso, as palavras de uma comunidade - por mais instável que fosse; a questão seria que este incidente talvez não tenha nada a ver com os problemas de tradução que se resumem sob o título "Freud e a língua alema", mas esteja totalmente relacionado com a problemática geral: "Os psicanalistas franceses e Freud", justamente.

No limite, o que é traduzir para uma nova geração de leitores de modo que esta nova geração não mais fale a mesma língua (na mesma língua), que uma grande parte da geração precedente - tradutores excluídos? Além disso, esta nova geração de leitores se encontra não nas "escolas" de analistas, mas nas 
universidades, lugar onde ler é ainda uma obrigação. Já há muito que os alunos de Lacan não se falam mais, de uma geração a outra, mesmo que por citaçōes, sobre a tradução de Freud, o que ainda parece a atitude mais "freudiana" $e$ que os freudianos possam continuar a discuti-lo, nem que seja para dar continuidade à psicanálise, teoria da fala, sem que se tenha de regulamentar a fala entre si, estando ou não de acordo. A harmonia de um texto, de um grupo (de um tratamento?), a harmonia pode ser a melhor ou a pior das coisas, e sabemos que o melhor pode ser a superfície, mesmo quando o pior está no fundo. Poderíamos, ao mesmo tempo, pleitear a referência ao uso linguageiro $\mathrm{c}$ abandonar um uso linguageiro, conforme se faça apelo à técnica ou a conceituaçāo?

Fica a melhor hipótese: tendo demonstrado que a relação com a língua freudiana, na França, é de uma grande constância, de um escrúpulo perfeito e é objeto de um trabalho aguerrido - cada psicanalista tendo sido formado no espírito de que conhecer Freud $\varepsilon$ apenas um detalhe,$- \epsilon$ evidente que a relação de estranhamento prometida por uma tradução nova vai provocar uma reação de entusiasmo e uma intensidade de reflexão como jamais se viu...

É a própria dificuldade de expressão que conduz os homens da infância à metafísica. ${ }^{20}$

Gianbattista Vico não era um especialista da linguagem infantil, mas tentou fundar a ciência nova, um caminho para a origem das leis, passando pelo estudo dos primeiros embalos linguageiros; uma teoria de e para a história. O que conduziria os psicanalistas, do infantil de uma língua, de uma linguagem ou de uma alma, à metapsicologia, senăo uma teoria que não renuncia à sua própria história? Dificuldades, liberdades de expressāo, co-presença das historias e de uma fala obstinada, submetida à linguagem, insubmissa em pensamento.

\section{Um método "utraquístico"}

Interessar-se pelo pensamento primário, pelas primeiras teorias mágicas do mundo, não está isento de alguma selvageria.

É nossa incumbéncia recolocar na alma humana o que o animismo nos ensina com respeito a natureza das coisas. ${ }^{21}$

Eis o eixo de transposição da metafísica especificada por Freud em Totem e tabu, sempre lembrando-se de que a primeira teoria completa do mundo é o animismo, que é preciso conceber enquanto "sistema intelectual".

20. G. Vico. Origines de la poésie el du droit. Paris, Cafe-Clima. 1987.

21. S. Freud. Totem et rabou. Paris, Payot, coll. "PBP", 1973, p. 107. 
A retransformação projetiva da metapsicologia repousa sobre a elaboração secundária que daria acesso a representaçōes do primário no pensamento. É justamente em Totem e tabu que a metapsicologia ressurge, desta vez um tanto distanciada da analogia com a paranóia (como grande construção de sistema) pelo assinalamento, determinado pela abordagem do animismo, de uma dificuldade que situa o teórico na descendência do homem primitivo exercendo-se em "substituir as leis naturais por leis biológicas". Este assinalamento é um alerta que controla o estudo da projeção:

Uma função intelectual nos é inerente e exige, de todos os materiais que se apresentam à nossa percepção ou ao nosso pensamento, unidade, coerência e inteligibilidade; e não teme estabelecer relaçōes inexatas já que, após certas circunstâncias, 6 incapaz de aprecnder as relaçōes corretas [...]. Nas afeeçỏes delirantes (a paranóia), o sistema é o que fica mais aparente, domina o quadro mórbido, mas também nāo deve ser negligenciado em outras formas de psiconeuroses. Em todos estes casos [antes de abordar a paranóia, Freud lembrava os "sistemas" do sonho e do sintoma], pode-se mostrar que foi efetuado um remanejamento do material psíquico em funçāo de um novo objetivo, remanejamento que, com frequência, fundamentalmente forçado, apesar de ser compreensível se nos colocamos do ponto de vista do sistema. ${ }^{22}$

Este alerta fundaria, por si só, os princípios de uma clínica da teorização, de uma psicopatologia do teórico: atenção aos remanejamentos forçados, tudo é questão de cireunstâncias psíquicas... na sistematização representativa do aparelho psíquico, especificamente.

A vida intelectual de Freud é, desta maneira, balizada pelas trocas tranferenciais que o forçaram a discernir sistematização e teorização. Fliess era um campeão da unificação intelectual; são sempre, de um modo ou de outro, pontos de unificação teórica que suportarão a patologia relacional e as diferenças, indo até a dissidência: diferenças de ponto de vista, remanejamentos em função de novos objetivos conceituais, com Adler e Steckel, depois com Jung, e ainda com Rank. Nos anos imediatamente anteriores a decisăo de empreender verdadeiramente os escritos metapsicológicos (1915), são justamente o estudo da língua fundamental do presidente Schreber, por um lado, e o estudo do animismo $\mathrm{c}$ da onipotência dos pensamentos, por outro, que terão preferencialmente ocupado Freud. A luta permanente da teoria contra a sistematização culminará, entre 1910 e 1912, exatamente em tomo do projeto de reflexão sobre a paranóia com Ferenczi, trabalho comum que se revelará impossivel em virtude dos contratempos transferenciais - contratempos que

22. Ibid., p. 133; citado por Jean Laplanche e J.-B. Pontalis, Vocabulaire de psychanalyse, Paris, PUF, 1967, P. 132. 
levarão Freud a tentar analisar mais adiante as funções (pulsionais) da sublimação na atividade teorizante. Pode-se constatar, na correspondência com Ferenczi, como a intenção metapsicológica se afastou da sistematizaçăo paranoica. Após o incidente da viagem a Sićlia, centrado em torno da recusa sintomática de Ferenczi em trabalhar em conjunto sobre o "caso" do presidente Schreber, e para inaugurar um trabalho interpretativo que não durará menos do que dois anos, Freud escreve: "Tive sucesso ai onde o paranoico fracassa" ${ }^{\text {"23 }}$, querendo indicar o caminho da sublimação necessária para a teoria, entre a homossexualidade e a paranóia. O conjunto desta questão deveria ser retraçado precisamente com o auxilio da correspondência Freud-Ferenczi, mais especificamente por uma leitura atenta das cartas trocadas em um período em que compreender os mecanismos da paranóia era o grande problema do momento, mobilizando a maioria das reflexões teóricas (ponto de partida, principalmente, daquilo que, sob o título efêmero: Metamorfoses e símbolos da libido, levara Jung à ruptura...). Contexto conflitivo e guerreiro, para um tema de reflexão que se tornará incidentemente o maior divisor, em um período em que se revelará a necessidade de fundar um bastião: a Associação Psicanalítica Internacional. Guerra dos fantasmas em 1911, realidade da guerra em 1915, pode-se compreender uma certa urgência em fixar os conceitos em uma metapsicologia "sólida".

Outro Esboço possível do problema, esta frase de Ferenczi para Freud:

O sr. me disse um dia que a psicanálise era uma ciência de fatos, de constatą̧óes no indicativo que não devem ser traduzidas no imperativo, o que seria paranóico. ${ }^{24}$

Tais trocas devem ser relacionadas com o programa de transposição da metapsicologia, pois escandem a produção da teoria freudiana a partir de uma psicopatologia das transferências sobre a teorizaçāo. Da mesma maneira, permitem constatar que Ferenczi talvez seja o único psicanalista do primeiro círculo a ter mantido a aposta, para os destinos da psicanálise, em uma posição metapsicológica no indicativo e não no imperativo.

Quanto às transferências para a teoria e para a teorização, Ferenczi não foi o último a observar a incidência da erotização da atividade de pensar - até no exercício da atividade científica - e chamar a atenção para os benefícios de que se pode gozar assim como dos possíveis deficits. É notável que suas aventuras clínicas, técnicas e teóricas o tenham levado a sustentar diretamente - diferentemente, é verdade, da abordagem de Freud, mas de maneira, no final das contas, concorrente - a reflexão sobre a paranóia e sobre a metapsicologia.

23. Carta de Freud a Ferenczi de 6 de outubro de 1910, in Correspondance, p. 231, op. cit.

24. Ibid., carta de Ferenczi a Freud, p. 229. 
Com relação à paranoiia, devemo-lhe esta notável formulação:

O paranóico projeta sobre a base da exigência etiológica mínima. [Ele] une manifestamente suas paixőes e idéias de perseguição cheias de desprazer ao fato de que efetivamente seu olhar aguçado reconhece, com exatidão, este infimo grau de interesse sexual permanente, inconsciente, que os seres humanos deixam aparecer para todos os seres vivos e que se poderia chamar tônus sexual das neuroses, exagerando, com seus próprios meios, apenas a quantidade. ${ }^{25}$

Como funciona, pois, "a base da exigência etiológica mínima" no movimento projetivo do pensamento teorizante - da atividade metapsicológica - para os pensamentos? Como a erotizaçăo da atividade de pensar, da simples reflexão da invenção da teoria (dever-se-ia ousar falar de uma fabulação conceitual, em um sentido positivo), se inscreve na linha energética de um "interesse sexual permanente" (assegurando a ligação entre curiosidade sexual e curiosidade intelectual)? Como ela interfere no "tônus sexual"... do teórico? Estas questôes remetem a certos critérios de cientificidade, eminentemente refutáveis ou ainda pouco partilháveis na comunidade científica, específicos da psicanálise.

Aquela que foi, certamente, a primeira conferência que teve por tema "A metapsicologia de Freud" foi organizada em Viena em 1922 a pedido de uma platéia inglesa e americana, sendo confiada a Ferenczi. Esta exposição levantava o essencial das questōes: a antinomia entre dados parciais, ponto de vista analítico e síntese, ponto de vista sistemático; os modelos da metafísica; o projeto de estabelecer as bases materiais do psiquismo normal; as relações com a biologia. Isto sempre explorando os principais conceitos ${ }^{26}$. Certos pontos da apresentação geral merecem ser lidos detalhadamente.

Para Ferenczi, "metafísica" designava a tentativa de explicação de qualquer fato de observação (mesmo do psíquico) por meio de leis (físicas e fisiológicas) conhecidas. Ele escreve:

A metapsicologia, em contrapartida, se propôs a tarefa aparentemente desesperada de estabelecer as bases materiais dos processos psíquicos a partir da observação dos próprios processos psiquicos, ou seja, de edificar, de alguma maneira, uma parte da biologia, da fisiologia e da física. ${ }^{27}$

Esta tarefa desesperada não conheceu precursores, segundo ele, senão em uma era pré-científica e ele propōe, inicialmente, considerar cum grano salis a metapsicologia - "sob uma forma cientificamente depurada - no animismo". Ele

25. S. Ferenczi "Paranoina", in Oewvres compleles, IV. Paris, Payol, 1982, p. 220.

26. S. Ferenczi. "La metapsychologie de Freud", in Oeuvres compleres. IV, op. cit. pp. $220-265$.

27. Ibid., P. 254. (Grifos nossos) 
justifica a audácia desta proposição, lembrando que os progressos da ciência do cérebro não haviam, até então, aberto espaço senäo a um tipo de "mitologia biológica ou molecular". Então, desde 1922, a questão está colocada nos termos de uma confrontação entre biologia ou neurobiologia e metapsicologia - esta devendo se desenvolver em uma psicologia explicativa. O projeto é este: alcançar, segundo Ferenczi, uma biologia metapsicológica. A metapsicologia de Freud deve oferecer "suportes especulativos que surgem, quer queira quer não, quando se estudam os processos psíquicos" e acerca dos quais não se tem dúvida de que "seråo igualmente confirmados pela biologia".

Descrevendo e criticando os pontos de vista tópico, dinâmico e econômico, Ferenczi mostra como uma psicopatologia deu lugar a psicanálise e como o desenvolvimento da psicanálise rumo à metapsicologia exige uma elaboração suplementar, que "retransforma" a psicopatologia e que, assim, compreende o "psiquismo normal". A metapsicologia - propõe ele - é um mecanismo físico do órgão psíquico.

No estágio atual de nossos conhecimentos, a mecânica psíquica corresponde; portanto, ao estágio da física em que a insuficiência dos instrumentos de medição impedia a verificação matemática dos dados: estes se apoiando exclusivamente nos testemunhos dos sentidos. Isto năo basta, no entanto, para que um homem lúcido recuse reconhecer o imenso progresso que representa o fato de dispor de uma mecanica psíquica, mesmo que rudimentar. ${ }^{28}$

Além da promessa da referência de Freud à física (para o modelo de conjetura, mas também em virtude de que as descobertas da física serão o modelo científico exemplar tendo destronado o antropocentrismo - assim como a psicanálise teria subvertido a concepção pré-científica do eu como centro do humano), notar-se-á que Ferenczi se interessava de perto pelos escritos dos físicos contemporâneos e principalmente pelos que, como Ernst Mach, não hesitavam em falar de "sublimação intelectual"29 e davam a impressão de ir em direção à psicologia.

Querendo, para concluir, enfatizar a importância da metapsicologia na história da ciência, Ferenczi retoma o sistema precursor - o animismo.

$\mathrm{O}$ animismo cometeu o erro "de projetar simplesmente sobre a natureza as experiências psíquicas do homem". As ciências da natureza "reagiram exaltando os méritos da exatidão, insistindo sobre o caráter mensurável dos processos "e atribuindo uma autêntica desonra às experiências de origem puramente psiquica".

29. Citado por S. Ferenczi, "La psychogénese de la mécanique" (1919) e "Supplement 1 . " (1920). pp. 44-52 e pp. 82 a 84, in Oeuvres completes, III. Paris, Payot, 1974. 
A metapsicologia "se esforça novamente para aproximar os conhecimentos da natureza por meio da introspecção: ela $\epsilon$, na verdade, pesquisa animista", mas sem negligenciar as descobertas das ciências. Ela merece, portanto, o nome de método utraquístico, pois não dispensa nenhuma das duas grandes fontes do conhecimento, nem o interior, o psíquico, nem o exterior, o das ciências naturais. Ela se esforça, atribuindo um valor justo aos dois tipos de experiência, para aproximar a verdade que pressentimos a uma distância assintomática ${ }^{30}$. Tomado ao mesmo tempo pelo problema de uma abordagem da verdade e pelo trabalho de nominação, Ferenczi forja um adjetivo que sofre a força contrária da oposição crença/determinismo. Utraquístico seria, na verdade, o indício - e a resultante de uma relação psicopatológica com a conviç̧ão, pressentindo, assim, diante de um auditório de "profanos", os riscos de deslizamento da doutrina sobre o dogma ou ainda do doutrinal para o doutrinário. Mesmo que saibamos que nomear um risco basta para preveni-lo, observemos a instantaneidade de um afastamento, no conferencista, em relação ao rigor de seu raciocínio. Littré nos informa que os "utraquistas" ou "calistinos" eram membros de uma seita da Boêmia, que reclamavam uma prática da comunhão sob as duas formas (o pão $\mathrm{c}$ o vinho, o corpo e o sangue). Certamente, pode-se supor em Ferenczi uma metaforização de dois tipos - o corpo e o psíquico.

O mesmo momento de pensamento será resumido um ano mais tarde, na introdução de Thalassa, em que Ferenczi pleiteia a livre circulação das noções entre biologia e psicanálise. $O$ descritivo permite facilmente que cada um fique em seu próprio domínio, mas a pesquisa de significação de um processo, a interpretação e a construção de um aparelho psíquico, condenam a que se recorra à análise. Passando logo da biologia a física, Ferenczi observa que as palavras "forças, atrações, resistências, inércia", descrevendo fenômenos provenientes da ciência são comparações cujo conhecimento está acessível apenas do lado do intelecto e do psíquico. Lembrando as analogias físicas do discurso metapsicológico ("tópico", "dinâmico", "econômico" eram qualificaçôes substantivas muito marcadas), acrescenta:

Acabei por admitir que não havia vergonha nestas analogias reclprocas e que poderíamos deliberadamente operar uma aplicação intensiva deste método, considerando-o como um passo inelutável e extremamente benéfico. Também, em meus trabalhos posteriores, não hesitei em preconizar este modo de trabalho que qualifiquei de utraquístico...

Não desprezar a analogia, sem vergonha, sem hesitação... o convite foi seguido diversamente, sabemos! Mas Ferenczi especificava ainda: 
...somos involuntariamente levados a medir a matéria pelo imaterial, e inversamente.

Ainda mais conciso, prossegue:

...qualquer fenômeno físico e físiológico requer também uma explicaçăo metaff́sica (ou psicológica) e [...] qualquer fenomeno psicologico demanda uma explicação metapsicológica (portanto, física). ${ }^{31}$

Voltar a estas leituras permite evidentemente constatar a que ponto a tentativa de definição do ponto de vista metapsicológico teria podido ser fecundado. Daí a necessidade de ainda pensar nele.

Tomar emprestado da física para contribuir com a biologia: a intenção de Freud foi regular e claramente afirmada, muito mais do que as esperanças de verificação que lhe são atribuídas, através de citaçōes com frequiencia truncadas. Sem negligenciar os outros campos conceituais, a psicanálise tinha, no entanto, de "se fazer por si mesma" e a função da metapsicologia neste empreendimento de fundação é completamente central - a ponto de continuar a operar com ela e conduzir seu movimento muito mais do que refundar o que quer que seja. Ferenczi, ainda af́, convidava a compreender e transmitir que "a abordagem metapsicológica 'Além do princípio de prazer', ou seja, além do mundo psíquico puro, nos permitiu [e ainda permite] pressentir esta linha imaginária, esta direção em que podemos esperar ver um dia fazer sua junçäo com as disciplinas da biologia e da fisica" $"$.

Certamente, nāo $e$ na direçåo em que, para alguns especialistas do sonho cerebral (Michel Jouvet, em particular), qualquer teoria freudiana do sonho se reduz à única proposição de que "o sonho é guardião do sono" "33 - redução que basta para que a exploração invalide, já que a proposição é falsa, o conjunto da teoria psicanalítica. Certamente não é nesta direção que se pode esperar ver a realização de uma linha imaginária de junção com a biologia.

Talvez fosse necessário também que uma forma de pensar a biologia pudesse já ter reunido o estatuto da especulação e da conjetura em física (junção que se encontra em Jacques Monod ${ }^{34}$ e que se reconhece também em François Jacob ${ }^{35}$, por exemplo) e "recupera", de alguma forma, o deslocamento do ponto de vista operado por Freud. Sob este ponto, um fragmento do Esboço de psicanalise é exemplar. Ele completa, aliás, o esquema de "transposição".

31. S. Ferenczi. "Thalassa" in Oeuvres completes, III, op. cit., p. 252.

32. "La metapsychologie de Freud", op. cit. p. 263.

33. M. Jouvet. Le sommeil et le réve., Paris, Odile Jacob, 1992.

34. J. Monod. Le hasard et la necessite. Essai sur la philosophie naturelle de la biologie noderne. Paris, Seuil, 1970.

35. F. Jacob, La logique du vivant. Paris, Gallimard, 1970 , e Le jeu des possibles. Paris, Seuil, 1981. 
Estivemos em posição de estabelecer a psicanálise sobre bases análogas às de qualquer outra ciência - escreve Freud -, da física, por exemplo. Em nosso domínio científico, como em todos os outros, trata-se de descobrir por trás das propriedades (as qualidades) diretamente percebidas dos objetos - [vê-se que o modelo metafisico se restabelece aqui com todo o rigor] - algo diferente que dependa menos da receptividade de nossos órgăos sensoriais e que aproxime ainda mais do que se supōe ser o estado de coisa real...

Aqui, um outro dado da transposição intervém, herdeiro da concepção da projeção paranóica no seio do princípio da "língua fundamental":

Logicamente, nāo esperemos atingir [o real], ja que estamos evidentemente obrigados a traduzir todas as nossas deduçóes na linguagem de nossas percepcöes...

É nesta desvantagem que se encontram "a natureza e o limite" da psicanalise, que Freud compara novamente com a natureza e com o limite das ciências físicas: o que a ciência tira das percep̧̧ōes (cujo rendimento pode ser aumentado por meios artificiais)

...é a descoberta de conexôes e interdependencias presentes no mundo exterior e que podem, de alguma forma, se reproduzir ou se refletir no mundo interior de nosso pensamento...

Vê-se que o esquema da projeção reflete isso e sua retransformaçāo para o mundo interior está aqui intata - a mais de trinta anos de distância! - tão próxima que não 6 mais o "olhar aguçado" do "paranóico", mas a "visão penetrante" do físico que estabelece as conexões. "Compreender", prever e, às vezes, modificar: a forma de proceder $\epsilon$ a mesma em qualquer direção, para o interior como para o exterior. Assim,

... pudemos descobrir certos procedimentos técnicos que nos permitem preencher as lacunas que subsistem nos fenomenos de nossa consciencia e utilizamos estes métodos técnicos como os físicos se servem da experimeniaçāo.

Constata-se a insistência da analogia. Mas, novamente, a questāo das projeçōes sobre a linguagem, o problema da conceituaçäo, assim como a metapsicologia os traz no mais elevado grau, a ponto de esboçar a aporia, recebem um complemento pela inscriçăo das particularidades do raciocínio por inferência em psicanálise.

Inferimos assim uma quantidade de processos em si mesmos "inconheciveis". Inserimos em seguida estes dentre os processos de que somos conscientes.

O plural "nós" contém a pluralidade dos psicanalistas, mas também o plural em trabalho na situaçāo de uma psicanálise. "Somos conscientes" pode muito bem significar a consciência do analista e a consciência do analisando. 
Quando, por exemplo, declaramos [se não é uma declaração comum, é sempre uma indicação, mesmo que implícita]: "aqui se inseriu uma lembrança inconsciente", é como se disséssemos: aqui aconteceu algo que nos ficou completamente "não concebível" (unfassbar), algo que, se acedesse à consciência, não teria podido ser descrito senão desta ou daquela maneira. ${ }^{36}$

Tendo advertido que "o real permaneceria para sempre não conhecível", Freud logo se defende da generalização que acaba de fazer, por assim dizer, do caso particular e da função e, principalmente, para limitar a analogia com a física, "reumanizando" o objeto da pesquisa psicanalítica - não é uma matéria indiferente. Claro, deve-se ter em conta a interação do aparelho psíquico do observador e do aparelho psíquico "observado", transferências e contratransferências. Apesar deste limite - o risco de erro devido à "equação pessoal" (expressão ferencziana) -, Freud prossegue a linha imaginária invocando os tempos futuros em que a mestria da equação pessoal será tal que não haverá mais necessidade de se preocupar com isto, não mais do que da carga das precauções antes impostas aos que faziam uso do microscópio, enquanto ainda se tratava de uma técnica nova!

Evidentemente, nós não atingimos estes tempos futuros... Além disso não é certo que consigamos, esquecendo o passado, as definições primeiras, os desvios fundadores.

Estaremos salvos por especulações provenientes de onde menos esperávamos? John Eccles, eminente neurologista e antigo colaborador do temível (para as "ciências humanas") Karl Popper, publicou há pouco um livro que ele apresenta como sua grande obra, e no qual - evolucionismo e biologia do cérebro como apoio - ele sustenta uma tese "dualista-interacionista" contra os excessos do materialismo biológico. Acha que a consciência năo pode se explicar unicamente em termos neuronais, e concebe uma passarela "entre espírito e cérebro": o pensamento, campo de consciência desprovido de massa e energia, ativaria, no entanto, certas partículas elementares presentes nas sinapses... O imaterial interviria, assim, sobre a matéria (que assegura suas condições de produção) e isto se explica pela física teórica, o campo de consciência seria análogo aos "campos de probabilidade" descritos pela mecânica quântica - o pensamento aumentaria a probabilidade dos acontecimentos neuronais, o cérebro não seria apenas emissor, mas receptor da consciência... ${ }^{37}$

John C. Eccles, certamente, ignora por completo que Freud faz apelo a teoria dos quanta, em 1915, ao longo de sua especulação metapsicológica, mais

36. S. Freud. Abrege de psychanalyse, pp. 72-73 (para o conjunto das citações). Tradução modificada (cf. $G W, X V I$, p. 127) para a ultima citaçăo. (Grifos nossos)

37. J.-C. Eccles. Evolution du cerveau ef crtarion de la conscience. Paris, Fayard, 1992. 
precisamente no artigo sobre o recalcamento. A idéia de quantum de afeto năo é, para ele, nova (ver "As psiconeuroses de defesa", de 1894), mas é, desta vez, imaginada em sua forma física para designar este "outro elemento do representante psiquico" que corresponde à pulsão "enquanto destacada da representação e encontra uma expressão conforme à sua quantidade em processos que são sentidos sob a forma de afetos". A "irradiação do corpo negro" de Max Planck (1900) é - se ousássemos dizer! - uma teoria do recalcamento. Um forno momo e sombrio deveria conter uma quantidade infinita de energia luminosa. A descontinuidade introduzida por Planck permite-lhe fazer a hipótese de que um átomo não podia absorver senão por meio de "feixes" - as quanta - de valor infinitamente pequeno, mas finito, determinado por uma constante $h$, a energia luminosa. A descontinuidade permite pensar a constante de uma energia "em pequenos feixes" destacados da continuidade do fenômeno. Para Freud, a hipótese do quantum de afeto intervém como hipótese necessária da descontinuidade, tornando possível a pesquisa separada daquilo "que acontece, em virtude do recalcamento, à representação e o que acontece com a energia pulsional que a cla está ligada". Pura especulação quântica, dir-se-ia na verdade. Ainda uma vez a metafísica para "fantasmar metapsicologicamente". E se a noção de "quantum" estava presente na ciência muito antes da descoberta de Max Planck, ela encontra em um dado momento sua condição para uma nova pertença - neste caso a de uma teoria do descontínuo que transforma, para o pensamento, a materialidade das imagens. É isto, sem dúvida, a física do psiquico.

O fisicalismo de Eccles traz, certamente - como se vangloriaram alguns uma nova "mensagem filosófica ${ }^{38}$. Em nome da consciência, diríamos. A biologia, em geral, e a neurobiologia, logicamente, nada ganham com este teoricismo. E não é com modelos assim promovidos que a psicanálise pode validamente ser posta em debate.

Um pouco mais de animismo "depurado cientificamente", um pouco menos de alma em nome da religiosidade científica, alguma prudência em relação às síntese filosóficas! E a metapsicologia não será negligenciável.

Resumos

Para el autor, es evidente que existe una psicopatologia freudiana y que su referencia es obligatoria. Sin embargo, es un hecho que las caracteristicas de su "bandera" permanecen imprecisas en la medida en que no se presta atención a lo "metapsicologico" que está implicado en su discurso. Es necesario acrecer también 
que el uso del termino "merapsicologia" por los psicoanalistas no esta protegido de las fuertes influencias ideologicas, en virtud de las aspiraciones del psicoanalisis a la "cientificidad".

Aproximando metapsicología y psicopatología, el autor trabaja lo que él considera como la invención de una perspectiva hasta entonces desconocida, de una perspectiva que define su objeto indicando la posicion del sujeto que observa: perspectiva del aparato psiquico hace mucho muy anunciada y posteriormente definida en términos de puntos de vista.

Les variations importantes que l'on constate aujourd'hui parmi les psychanalystes sur l'usage des termes de "métapsychologie" et de "psychopathologie" recouvrent des différences sensibles quant à leur sens et à leur portée. Dans la présente contribution, les auteurs introduisent à une réflexion sur la place de l'invention de la métapsychologie dans l'oeuvre de Freud, corrélativement à une définition que reçoit alors la psychopathologie. Le recours à l'histoire du mouvement psychanalytique est nécessaire s'il s'agit, en effet, de savoir de quels oublis est affectée la psychanalyse lorsque est idéologiquement négligé le rapport de sens entre métapsychologie et psychopathologie: oublie de la valeur mnésique du symptôme, oubli des fonctions de reconnaissance et de nomination, oubli de tout ce qu'engagent "projection", "transposition", "traduction", "transfert" etc. La transposition de la métaphysique en métapsychologie - énoncée notamment à la faveur de la paranoïa - permet ici de rappeler la place accordé à l'animisme et ainsi à une physique de la psychologie.

The important variations that one notices today in the use make of the terms "metapsychology" and "psychopathology" cover noticeable differences in the meaning and the scope of these terms. In the present contribution, the authors present a reflection on the place of the invention of metapsychology in Freud's work, correlatively to a definition of psychopathology that is then provided. Indeed, we have to go back to the history of the psychoanalytic mowvement, if we want to know how psychoanalysis could have been affected by forgetting when the relation of meaning between metapsychology and psychopathology is ideologically neglected: forgetting about the mnesic value of the symptom, forgetting about the function of recognition and nomination, forgetting what is involved in "projection". "transposition". "translation", "transfert" etc. The transpositions of metaphysique into metapsychology - stated notably in favour of paranoia - has made it possible to stress the role of animism and thus of a physics of psychology. transfert 